\title{
Antiabsence Effects of Safranal in Acute Experimental Seizure Models: EEG and Autoradiography
}

\author{
Hamid R. Sadeghnia a,f, Miguel A. Cortez ${ }^{\mathrm{c}, \mathrm{d}, \mathrm{e}, \mathrm{f}}$, Dick Liu ${ }^{\mathrm{f}}$, Hossein Hosseinzadeh ${ }^{\mathrm{b}}$, \\ O. Carter Snead, $3^{\text {rd } c, d, e, f^{*}}$ \\ ${ }^{a}$ Department of Pharmacology, Faculty of Medicine and ${ }^{\mathrm{b}}$ Pharmaceutical Research Center, Faculty of Pharmacy, Mashhad \\ University of Medical Sciences, Mashhad, Iran. ${ }^{\mathrm{c}}$ Department of Pediatrics, Faculty of Medicine, University of Toronto, \\ 555 University Avenue, Toronto, ON Canada, ${ }^{\mathrm{d}}$ The Bloorview Epilepsy Research Program, ${ }^{\mathrm{e}}$ Division of Neurology and ${ }^{\mathrm{f}}$ \\ Neuroscience and Mental Health Program Research Insitute, Hospital for Sick Children, Toronto, ON Canada.
}

Received, December 13, 2007; Revised, April 29, 2008; Accepted, May 7, 2008; Published, May 13, 2008.

ABSTRACT - PURPOSE. We examined the
effect of safranal, a constituent of Crocus sativus, in
acute experimental animal models of generalized
absence seizures. METHODS. the effect of acute
systemic administration of safranal on latency to
seizure onset as well as spike and wave discharches
(SWD) duration following pharmacologically-
induced absence seizures was investigated in wild-
type mice. We further characterized its effects on
the GABAergic system through the regional
modification of [ $\left.{ }^{3} \mathrm{H}\right]$ flunitrazepam,
benzodiazepine agonist binding site and [ $\left.{ }^{3} \mathrm{H}\right]$
CGP54626A, a GABA ${ }_{\mathrm{B}}$ receptor antagonist binding
site in mouse brain. RESULTS. The systemic
administration of safranal resulted in a significant
and dose-dependent attenuation in experimental
absence seizures elicited by either $\gamma$-butyrolactone
(GBL), baclofen (BAC) or low doses of GABA ${ }_{\mathrm{A}}$
receptor antagonists; pentylenetetrazole (PTZ),
picrotoxin (PTX) and bicuculline (BMC). After a
single intraperitoneal administration of safranal
(291 mg/kg), no changes in baseline electrocorticographic (ECoG) recording were observed, however, a significant decrease in $\left[{ }^{3} \mathrm{H}\right]$ flunitrazepam binding was seen in the cortex $(33.16 \%, \mathrm{p}<0.001)$, hippocampus $(27.36 \%, \mathrm{p}<0.01)$ and thalamus $(29.91 \%, \mathrm{p}<0.01)$ of mouse brain, while the $\left[{ }^{3} \mathrm{H}\right] \mathrm{CGP} 54626 \mathrm{~A}$ binding did not show any modification in the same brain regions. CONCLUSION. These data indicate that there is an antiabsence seizure property in safranal and its effect may be due to modifications on the benzodiazepine binding sites of the $\mathrm{GABA}_{\mathrm{A}}$ receptor complex.

\section{INTRODUCTION}

Generalized absence (petit mal) seizures are clinically, neurophysiologically and pharmacologically unique and differ from other seizure types (1). Typical absence seizures are characterized behaviorally by a paroxysmal loss of consciousness of abrupt and sudden onset and offset that is associated with bursts of bilaterally synchronous spike and wave discharges (SWD) measuring about $3 \mathrm{~Hz}$ in the electroencephalogram (EEG), with no aura or postictal state (2). Absence seizures are pharmacologically unique, responding only to ethosuximide, trimethadione, valproic acid, or benzodiazepines and being resistant to or made worse by phenytoin, barbiturates, or carbamazepine $(2,3)$. The mechanism that generates absence seizures appears to involve an alteration in the circuitry between the thalamus and the cerebral cortex $(2-4,5)$ and perturbations in the presynaptic release of glutamate and GABA within the thalamocortical circuitry have been demonstrated in several animal models of absence seizures (6-8).

Safranal (2, 6, 6-trimethyl-1, 3cyclohexadiene-1-carboxaldehyde, $\left.\mathrm{C}_{10} \mathrm{H}_{14} \mathrm{O}\right)$ is a monoterpene aldehyde, formed in saffron (Crocus sativus L.) by hydrolysis from picrocrocin during drying and storage. Safranal is a main constituent of the essential volatile oil responsible for the characteristic saffron odor and aroma (9).

It has been previously reported that saffron extract and some of its active constituents (i.e. safranal)

Corresponding Author: Dr. O. Carter Snead $3^{\text {rd }}$, Division of Neurology, The Hospital for Sick Children, Toronto, ON, Email: carter.snead@sickkids.ca 
have anticonvulsant effects in both pentylenetetrazole (PTZ) and maximal electroshock (MES) models in mice $(10,11)$. Moreover, safranal attenuated cerebral ischemia induced oxidative damage in rat hippocampus (12) and also had a protective effect against both clonic and tonic phases of PTZ-induced seizures. This protection was abolished by flumazenil, a benzodiazepine binding site antagonist (12). It was also documented that agents affecting the clonic phase of PTZinduced seizure may have anti-absence seizure activity $(13,14)$. Therefore, we conducted this study to test the effect of safranal on experimental animal models of generalized absence seizures. For further characterization of the safranal effect on the GABAergic system, we also studied regional modification of $\left[{ }^{3} \mathrm{H}\right]$ flunitrazepam, a benzodiazepine binding site agonist, and $\left[{ }^{3} \mathrm{H}\right]$ CGP54626A, a GABA $\mathrm{B}$ receptor antagonist binding site in mouse brain by safranal.

\section{MATERIALS AND METHODS}

\section{Animals}

Male C57BL/6 mice (Charles River Labs, Wilmington, MA), weighing 20-30 g, were used for all experiments. These animals were housed in a pathogen-free facility on a $12 \mathrm{hr}$ light/dark schedule and with ad lib access to food and water. The same animals were used for all experiments with 4-5 recovery days between the experiments.

\section{Drugs}

$\gamma$-Butyrolactone (GBL), pentylenetetrazole (PTZ), picrotoxin (PTX) and (-) baclofen (BAC) were obtained from Sigma (St. Louis, MO). (-) Bicuculline methochloride (BMC) and $\left[{ }^{3} \mathrm{H}\right]$ CGP $54626 \mathrm{~A}$ with specific activity of $40 \mathrm{Ci} / \mathrm{mmol}$ were obtained from Tocris Cookson Inc (St. Louis, MO). $\left[{ }^{3} \mathrm{H}\right]$ flunitrazepam with specific activity of 85 $\mathrm{Ci} / \mathrm{mmol}$ was obtained from New England Nuclear (Boston, MA). Safranal was purchased from Fluka (St. Gallen, Switzerland). Safranal is a yellow liquid $(\mathrm{d}=0.98 \mathrm{~g} / \mathrm{ml} ; \mathrm{Mw}=150.22)$ that was injected in a volume of $0.1,0.2$ and $0.4 \mathrm{ml} / \mathrm{kg}$ using a Hamilton syringe.

All other chemicals used for autoradiography study were obtained from Sigma (St. Louis, MO).

\section{Surgery and electrocorticographic (ECoG) recordings}

Anesthesia was achieved with a single intraperitoneal (i.p.) injection of pentobarbital (35 $\mathrm{mg} / \mathrm{kg}$, MTC Pharmaceuticals, Canada) and lasted for approximately $2 \mathrm{~h}$. All surgeries consisted of chronic stereotaxic implantation of two frontal and two parietal monopolar epidural electrodes. All four electrodes were stabilized using dental acrylic and two small screws. Following surgery, animals were returned to the animal facility for a 3-day recovery period. All ECoG recordings were made with animals in the freely moving state within shielded, heated, clear Plexiglas containers so that the behavioral response to the drug could be observed and correlated with any drug-induced ECoG event. The ECoG was recorded continuously for $1 \mathrm{~h}$ before and for $2 \mathrm{~h}$ after the administration of any seizure inducing drug, between 10:00 $\mathrm{h}$ and 13:00 $\mathrm{h}$. The digitized ECoG were amplified and filtered between 1 and $100 \mathrm{~Hz}$ and stored for off-line analyses. SWD were quantified in the ECoG activity on the basis of published criteria (15-17). Briefly, a spike and wave discharge was identified as such if it included a train of sharp spikes and slow waves with an amplitude 2-fold or higher than baseline and a frequency between 5 and $9 \mathrm{~Hz}$, whereas the minimum duration of the train was one second.

\section{Acute absence seizure model}

Experimental absence seizures were induced by administering either $\gamma$-butyrolactone $(100 \mathrm{mg} / \mathrm{kg}$, i.p.), (-) baclofen $(20 \mathrm{mg} / \mathrm{kg}$, i.p.), or one of the $\mathrm{GABA}_{\mathrm{A}}$ receptor $\left(\mathrm{GABA}_{\mathrm{A}} \mathrm{R}\right)$ antagonists PTZ (30 $\mathrm{mg} / \mathrm{kg}$, i.p.), BMC (5 $\mathrm{mg} / \mathrm{kg}$, i.p.) and PTX (1.5 $\mathrm{mg} / \mathrm{kg}$, i.p.) (17). With regards to the $\mathrm{GABA}_{\mathrm{A}} \mathrm{R}$ antagonists, the doses were selected based on the preliminary studies to determine the $\mathrm{CD}_{100}$ (minimal dose to induce absence seizures in $100 \%$ of animals).

The absence seizures induced by these agents were characterized by $7 \mathrm{~Hz}$ bilaterally synchronous SWD that were associated with behavioral arrest, facial myoclonus and vibrissal twitching (17).

In all experiments, safranal (either 72.75 $\mathrm{mg} / \mathrm{kg}$, or $145.5 \mathrm{mg} / \mathrm{kg}$ or $291 \mathrm{mg} / \mathrm{kg}$ ) was 
administrated i.p. 30 minutes before these seizure inducing agents.

\section{Autoradiographic studies}

Four male wild-type mice (20-30g) were treated with safranal (291 mg/kg, i.p.) and 30 minutes after, the mice were sacrificed by decapitation and the brains were rapidly removed and immediately immersed in 2-methylbutane at $-35{ }^{\circ} \mathrm{C}$. Coronal sections were cut from anterior to posterior boundaries of cerebral cortex at $20 \mu \mathrm{m}$ at $-20{ }^{\circ} \mathrm{C}$ and thaw-mounted onto gelatin-coated slides that were dried and stored at $-80{ }^{\circ} \mathrm{C}$ until used (18). Four control mice received saline solution, only. Timing and dose were selected based on preliminary studies as well as ECoG recording data.

\section{$\left[{ }^{3}\right.$ H] CGP54626A autoradiography}

$\left[{ }^{3} \mathrm{H}\right]$ CGP54626A autoradiography was performed as described elsewhere $(19,20)$. The slides were kept at room temperature for 1-2 hours and then preincubated for 15 minutes in Krebs-Henseleit buffer (containing $120 \mathrm{mM} \mathrm{NaCl}, 6 \mathrm{mM}$ glucose, $20 \mathrm{mM}$ Tris, $4.7 \mathrm{mM} \mathrm{KCl}, 1.8 \mathrm{mM} \mathrm{CaCl}_{2} 2 \mathrm{H}_{2} \mathrm{O}, 1.2$ $\mathrm{mM} \mathrm{KH} \mathrm{KH}_{2} \mathrm{PO}_{4}, 1.2 \mathrm{mM} \mathrm{MgSO}$, pH 7.4). Total binding was performed by incubating $\left[{ }^{3} \mathrm{H}\right]$ CGP $54626(2 \mathrm{nM})$ for 2 hours at room temperature in Krebs-Henseleit buffer with the appropriate tissue sections. Nonspecific binding was defined in the presence of $10^{-5} \mathrm{M}(-)$ baclofen.

\section{$\left[{ }^{3} \mathrm{H}\right]$ Flunitrazepam autoradiography}

$\left[{ }^{3} \mathrm{H}\right]$ Flunitrazepam autoradiography was performed based on the method of Carlson and colleagues with some modification, as reported before $(21,22)$. Briefly, after preincubation in $50 \mathrm{mM}$ Tris- $\mathrm{HCl}$ buffer ( $\mathrm{pH} 7.4$ ) for 30 minutes at $4^{\circ} \mathrm{C}$, the slides were incubated with $1 \mathrm{nM}\left[{ }^{3} \mathrm{H}\right]$ flunitrazepam for 60 minutes $\left(4^{\circ} \mathrm{C}\right)$. A total of $10 \mu \mathrm{M}$ flunitrazepam was used to determine nonspecific binding.

\section{Quantitative densitometry}

The autoradiographic data were analyzed as reported previously (23). Dried tissue sections were opposed to hyperfilm-bmax film (Amersham, Arlington, IL) with $\left[{ }^{3} \mathrm{H}\right]$ microscale standards
(Amersham) for 2 to 3 weeks at room temperature. The films were developed in D-19 (Kodak, Rochester, NY), fixed, and air-dried. Quantitative analysis of the resulting autoradiograms was performed densitometrically using a microcomputer-based densitometer system (MCID; Imaging Research; Ontario, Canada). Briefly, a standard curve between the optical density of $\left[{ }^{3} \mathrm{H}\right]$ standards and tissue radioactivity equivalents (pmol/mg of tissue) were constructed using a nonlinear regression analysis. The average optical density values of the selected brain regions were in the linear portion of this standard curve. The value (measured in $\mathrm{pmol} / \mathrm{mg}$ ) in each brain region (cortex, hippocampus, and thalamus) was calculated by interpolation using the image analyzer. For each structure, 10 optical density readings were taken from at least three sections and averaged $(20,22)$.

\section{Statistical analysis}

Data were expressed as means \pm SEM. Analysis of variance (one-way or two-way) followed by Tukey's or Bonferroni's post hoc test as well as two-tailed unpaired student t-test was used for statistical evaluation. The p-values less than 0.05 were considered to be statistically significant.

\section{RESULTS}

\section{Effect of safranal on experimental acute absence seizures}

Safranal had no effect on baseline ECoG recording (Fig. 1A). The systemic administration of either $\lambda$ butyrolactone (GBL, $100 \mathrm{mg} / \mathrm{kg}$ ) or baclofen (BAC, $20 \mathrm{mg} / \mathrm{kg}$ ), resulted in absence seizures in all mice which were characterized by bilaterally synchronous SWD on the ECoG (Fig. 1B, D) and behaviorally associated with facial myoclonus, vibrissal twitching, and arrest of motor activity. Similarly, the systemic administration of the low doses of $\mathrm{GABA}_{\mathrm{A}} \mathrm{R}$ antagonists (either PTZ, 30 $\mathrm{mg} / \mathrm{kg}$; or PTX, $1.5 \mathrm{mg} / \mathrm{kg}$; or BMC, $5 \mathrm{mg} / \mathrm{kg}$ ) (Fig. $1 \mathrm{~F})$ resulted in ECoG and behavioral changes consistent with absence like seizures. Figures 1C, $1 \mathrm{E}$ and $1 \mathrm{G}$ illustrate $\mathrm{ECoG}$ on safranal pretreated mice with absence seizures induced by GBL, BAC and $\mathrm{BMC}$, respectively. 
Figure 1

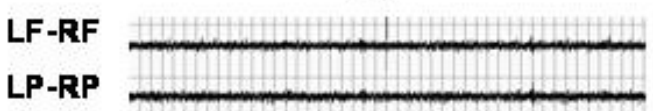

$\mathbf{B}$

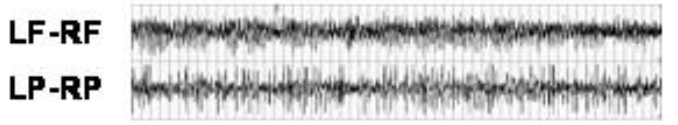

C

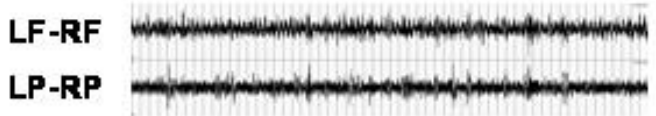

D

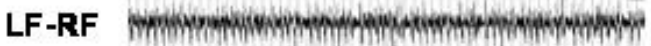

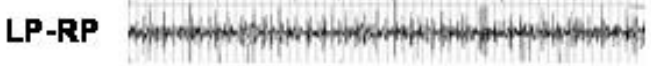
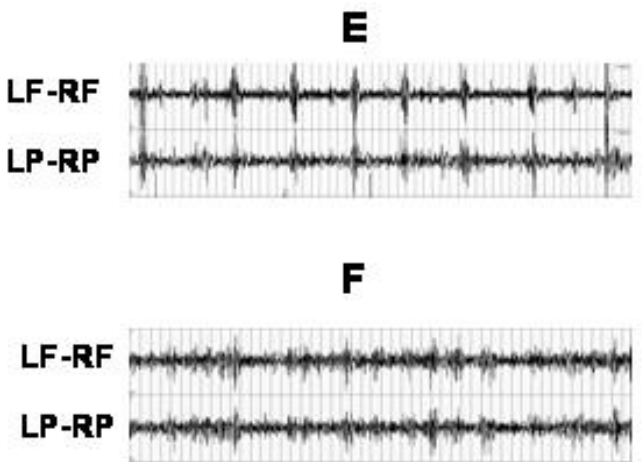

$\boldsymbol{G}$

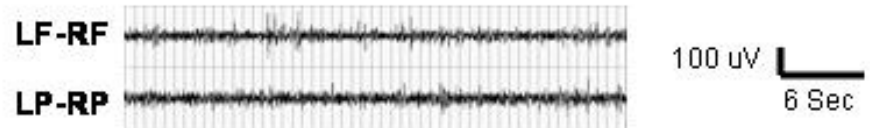

Figure. 1. Electrocorticographic $(\mathrm{ECoG})$ recordings of wild type mice received safranal and GBL, BAC or BMC alone or together with safranal. In all ECoG figures, $F-F$ and $P-P$ represent the differential recording from the left and right frontal and parietal electrodes, respectively. (A) Baseline ECoG $20 \mathrm{~min}$ after safranal administration (291 mg/kg). (B) ECoG 20 min after $100 \mathrm{mg} / \mathrm{kg}$ of GBL. (C) ECoG $20 \mathrm{~min}$ after $100 \mathrm{mg} / \mathrm{kg}$ of GBL in a mouse pretreated with safranal (291 mg/kg). (D) ECoG $20 \mathrm{~min}$ after $20 \mathrm{mg} / \mathrm{kg}$ of BAC. (E) ECoG $20 \mathrm{~min}$ after $20 \mathrm{mg} / \mathrm{kg}$ of BAC in a mouse pretreated with safranal (291 mg/kg). (F) ECoG $30 \mathrm{~min}$ after $5 \mathrm{mg} / \mathrm{kg}$ of BMC. (G), ECoG $30 \mathrm{~min}$ after $5 \mathrm{mg} / \mathrm{kg}$ of BMC in a mouse pretreated with safranal $(145.5 \mathrm{mg} / \mathrm{kg})$. All drugs were administered intraperitoneally. Administration of these pro-absence agents resulted in the bilaterally synchronous SWD shown. These paroxysms were associated with absence-like behavior in all animals that were tested, namely facial myoclonus, vibrissal twitching, and arrest of motor activity. Administration of PTZ $(30 \mathrm{mg} / \mathrm{kg}$, i.p.) and PTX (1.5 mg/kg, i.p.) produced EEG and behavioral findings similar to those shown for BMC and GBL. 
Except for PTZ induced seizures, latencies to seizure onset elicited by GBL, BAC, PTX and BMC were significantly increased by safranal, in a dose-dependent manner (Fig. 2A-E).

Figure 2 - A
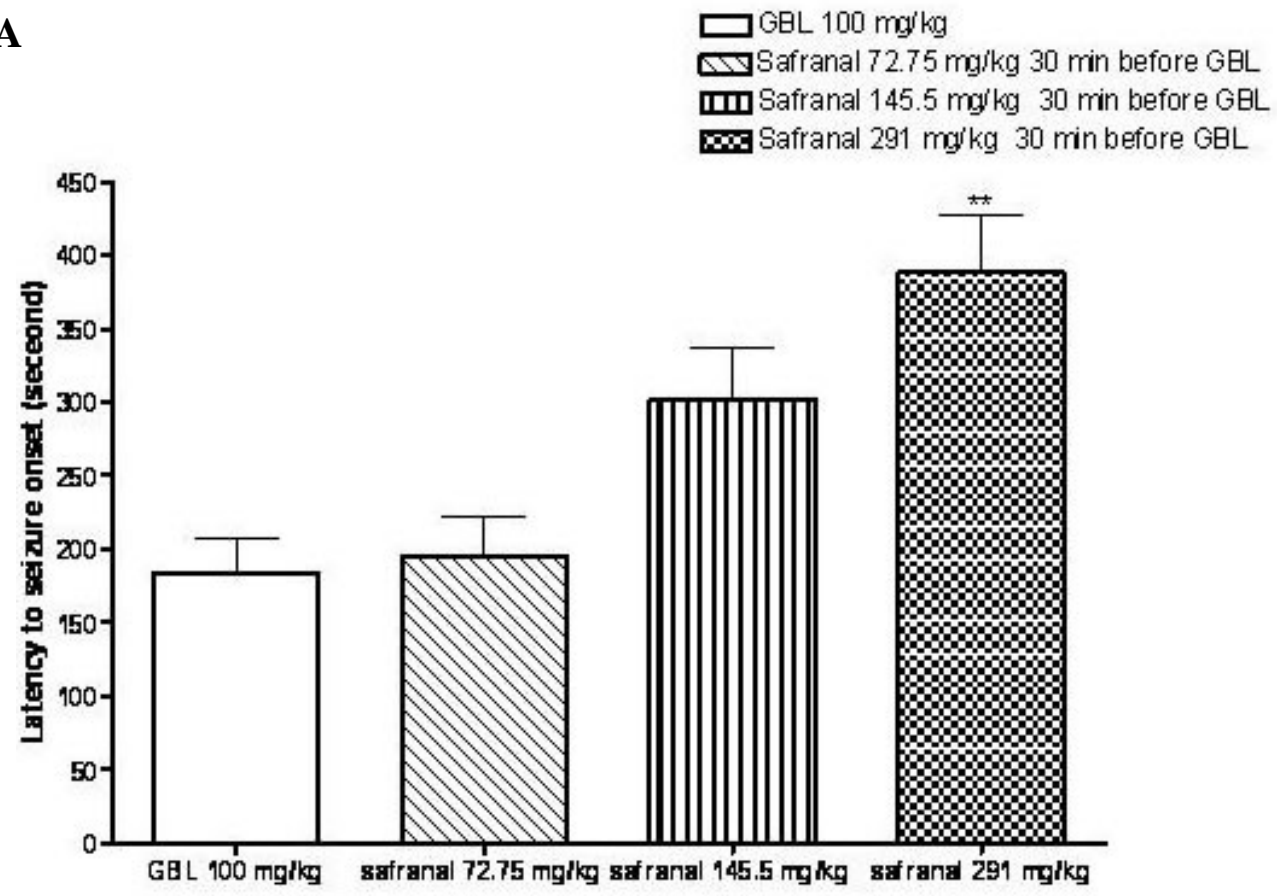

Figure 2 - B

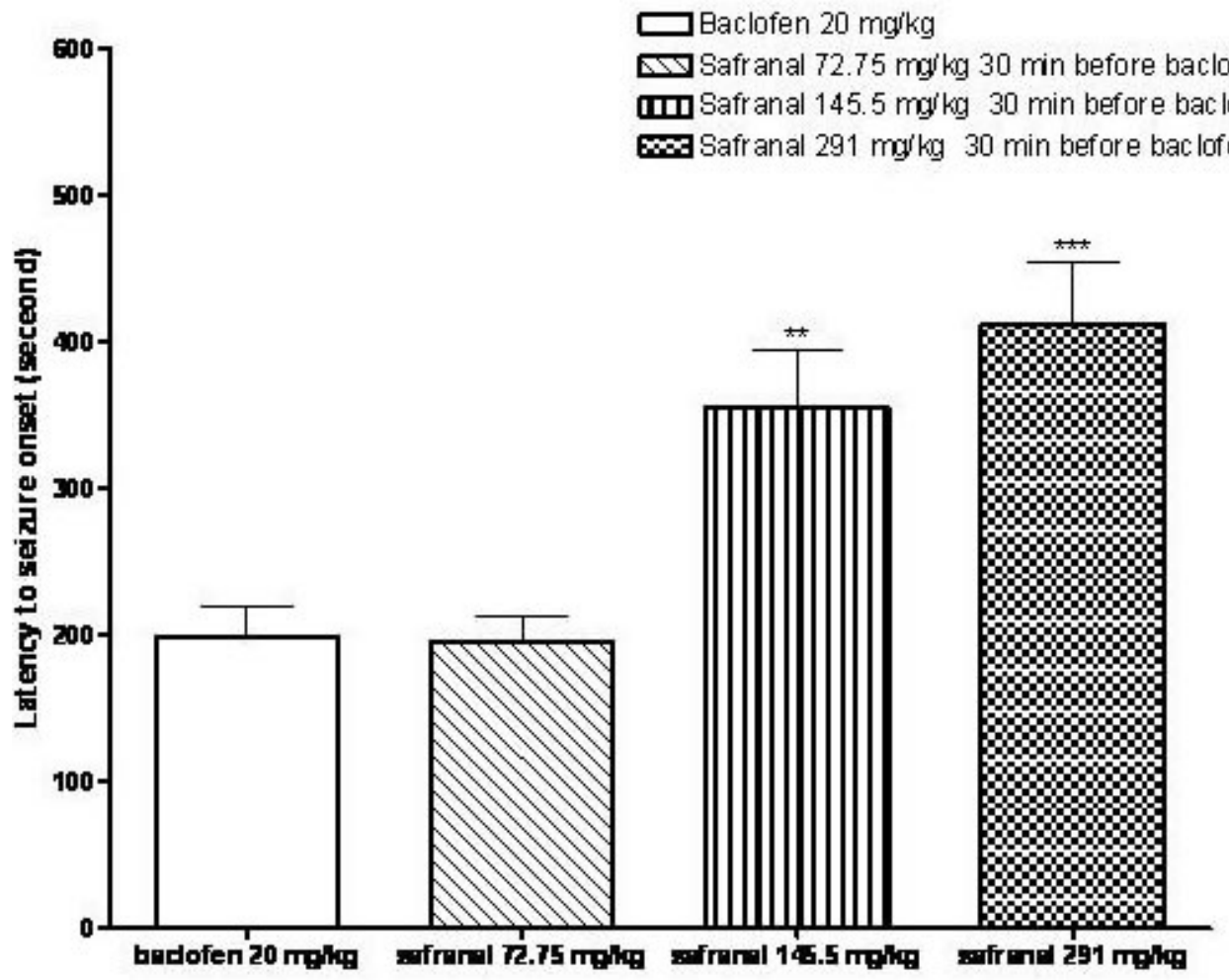


Figure 2 - C

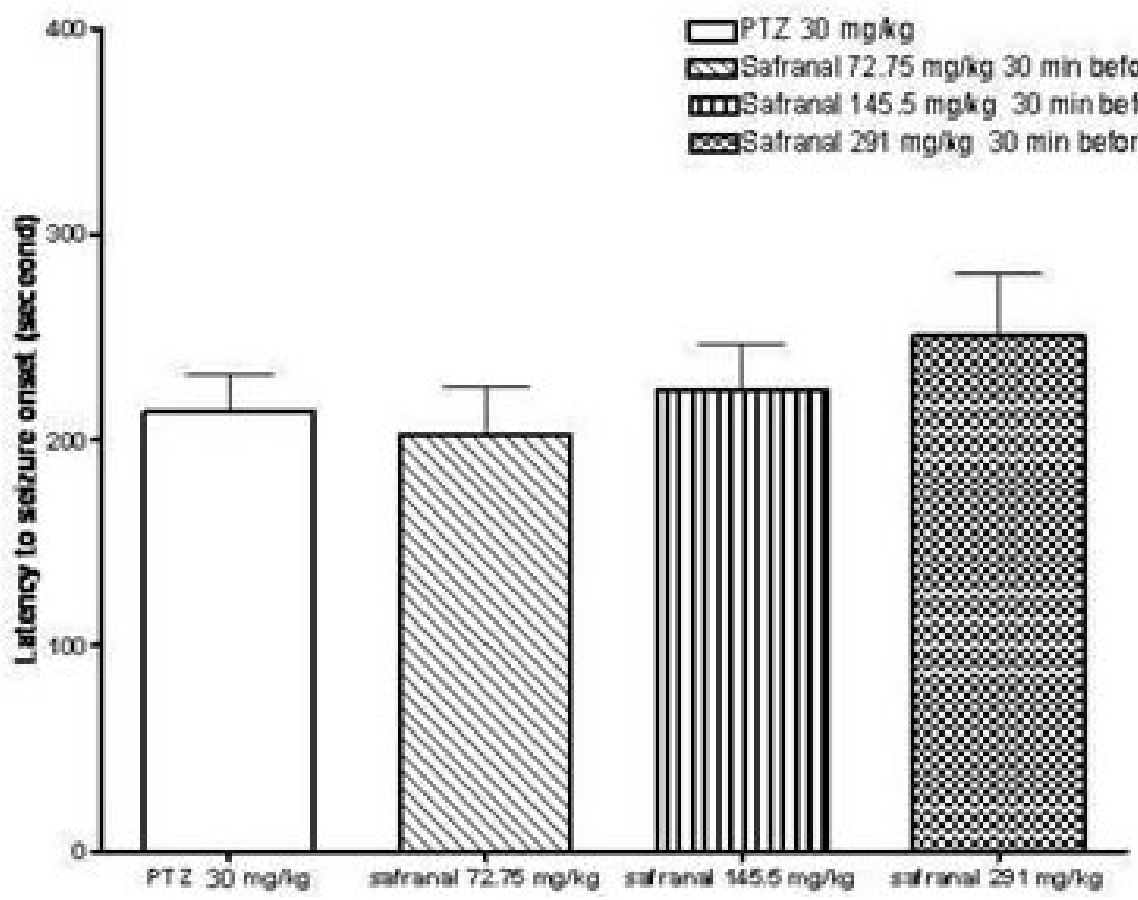

Figure 2 - D

$\square$ PTX $1.5 \mathrm{mg} / \mathrm{kg}$

$\triangle$ Safranal $72.75 \mathrm{mg} / \mathrm{kg} 30 \mathrm{~min}$ before PTX mSafranal $145.5 \mathrm{mg} / \mathrm{kg} 30 \mathrm{~min}$ before PTX

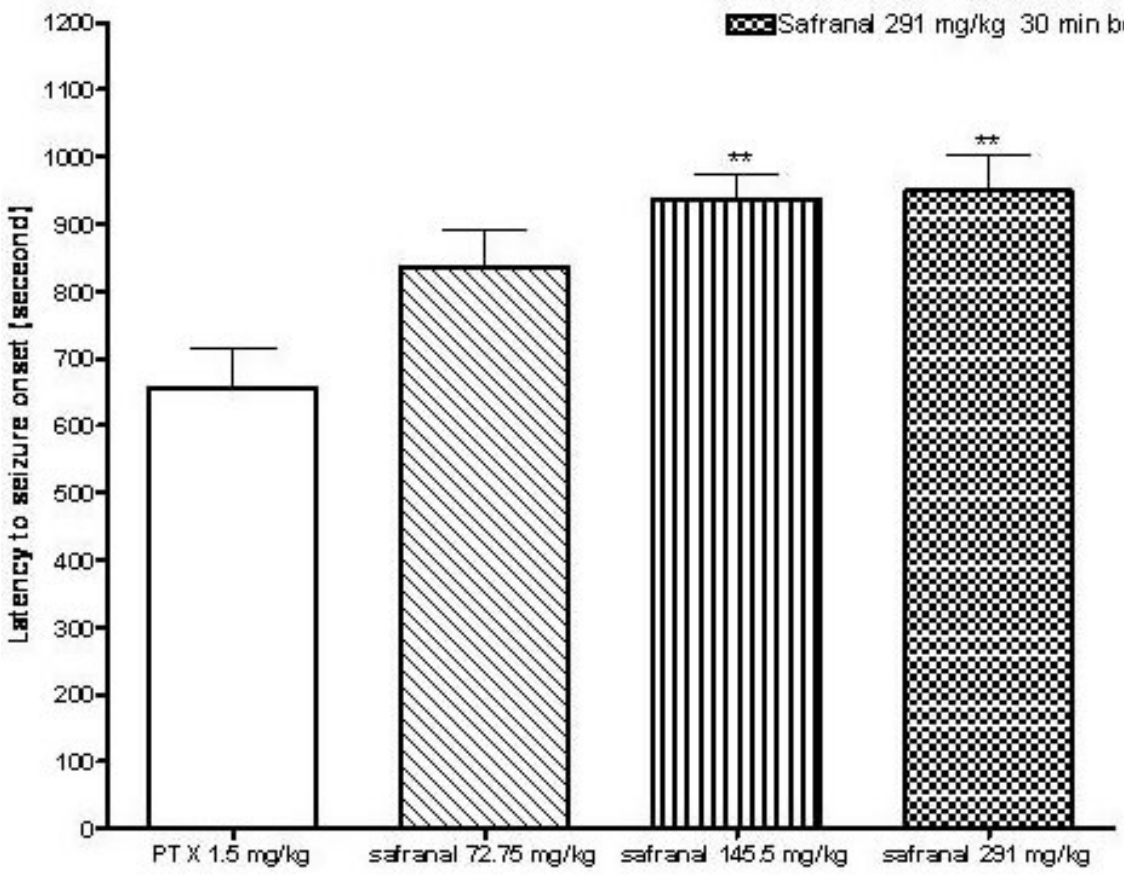


Figure 2 - E

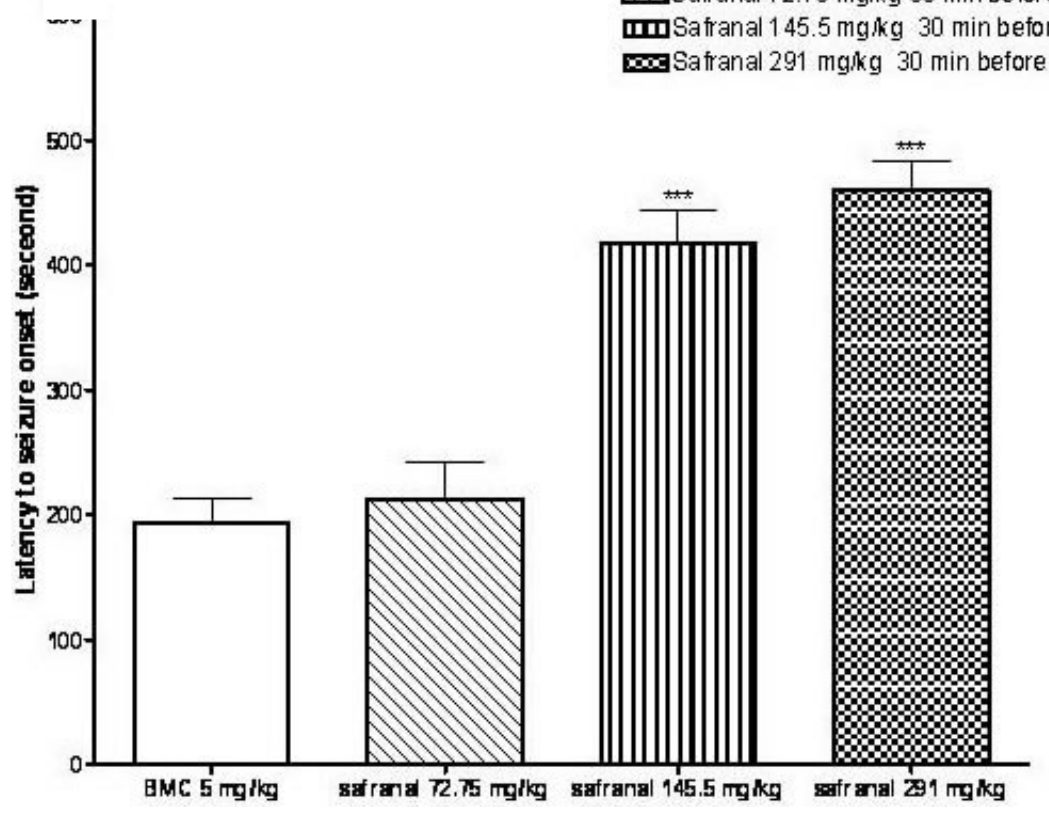

Fig. 2. Effect of safranal on latency to seizure onset induced by GBL (100 mg/kg), BAC (20 mg/kg), PTZ (30 mg/kg), PTX $(1.5 \mathrm{mg} / \mathrm{kg})$ and BMC $(5 \mathrm{mg} / \mathrm{kg})$. All drugs were administered intraperitoneally. (A) Effect of safranal on latency to seizure onset induced by GBL (100 mg/kg). (B) Effect of safranal on latency to seizure onset induced by BAC (20 mg/kg). (C) Effect of safranal on latency to seizure onset induced by PTZ (30 mg/kg). (D) Effect of safranal on latency to seizure onset induced by PTX $(1.5 \mathrm{mg} / \mathrm{kg})$. (E) Effect of safranal on latency to seizure onset induced by BMC $(5 \mathrm{mg} / \mathrm{kg})$. Values are mean \pm SEM ( $\mathrm{n}=6-8) .{ }^{* *} \mathrm{p}<0.01,{ }^{* * *} \mathrm{p}<0.001$ as compared to control group (One-way ANOVA followed by Tukey’s test).

Pretreatment with safranal resulted in a significant and dose-dependent decrease in the SWD duration following GBL, BAC, PTZ and BMC administration. All doses of safranal significantly decreased SWD duration following PTX-induced absence seizures (Fig. 3A-E).

Figure 3 - A

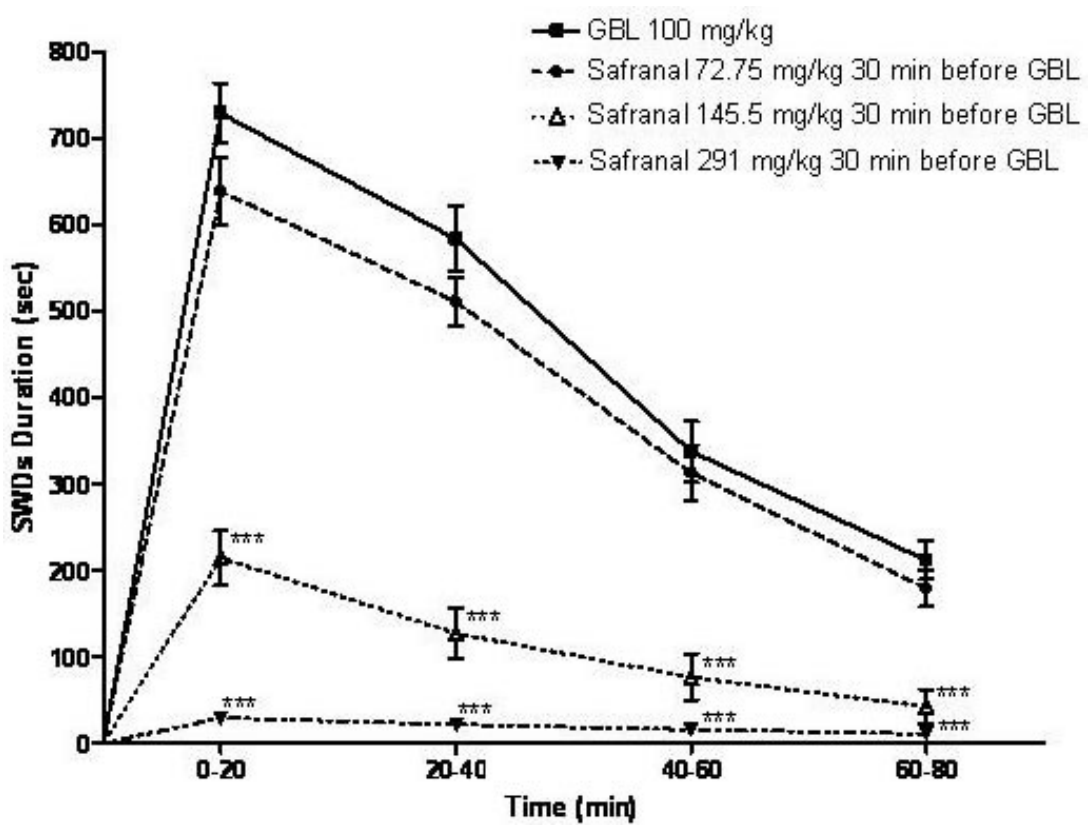




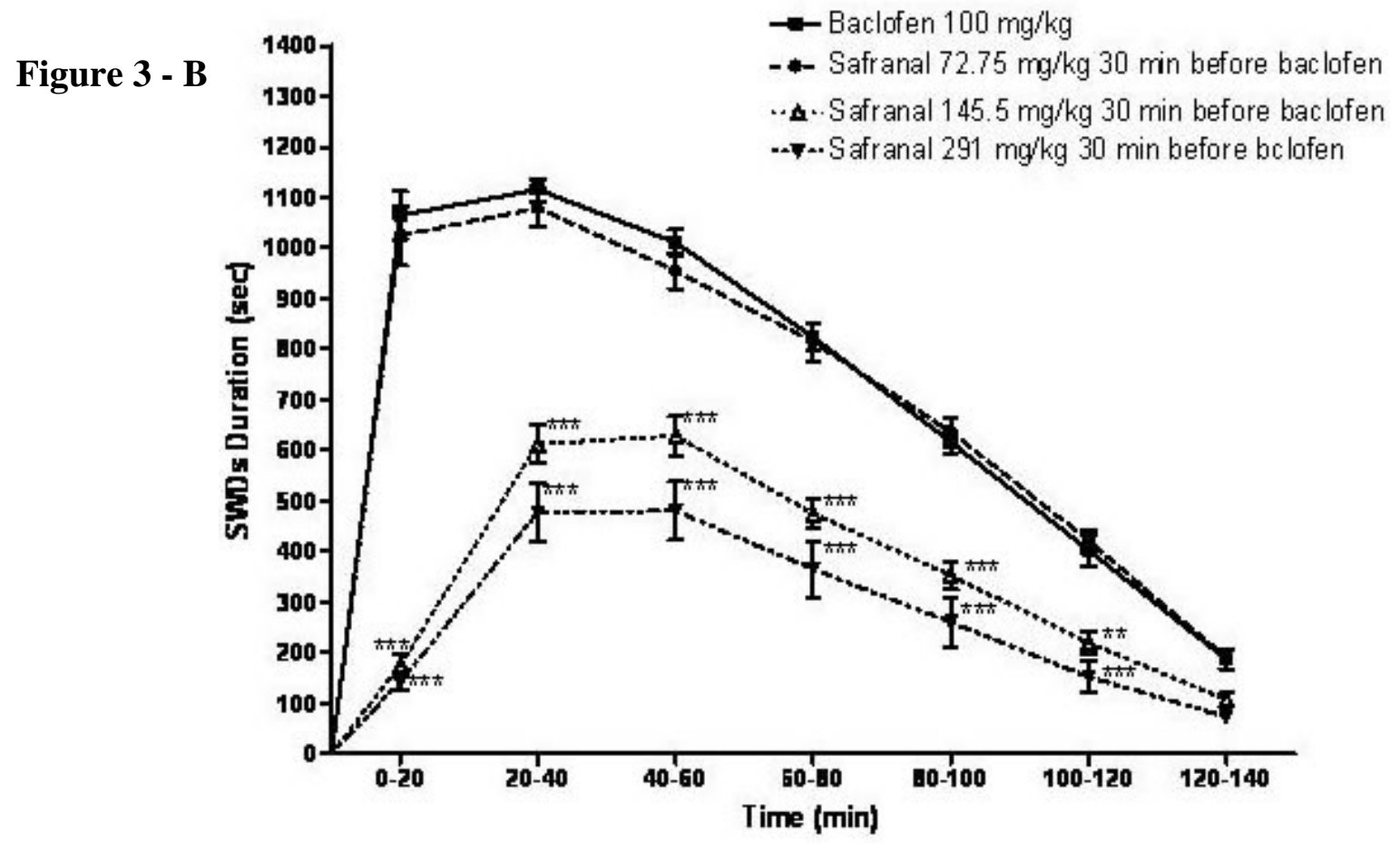

Figure 3 - C

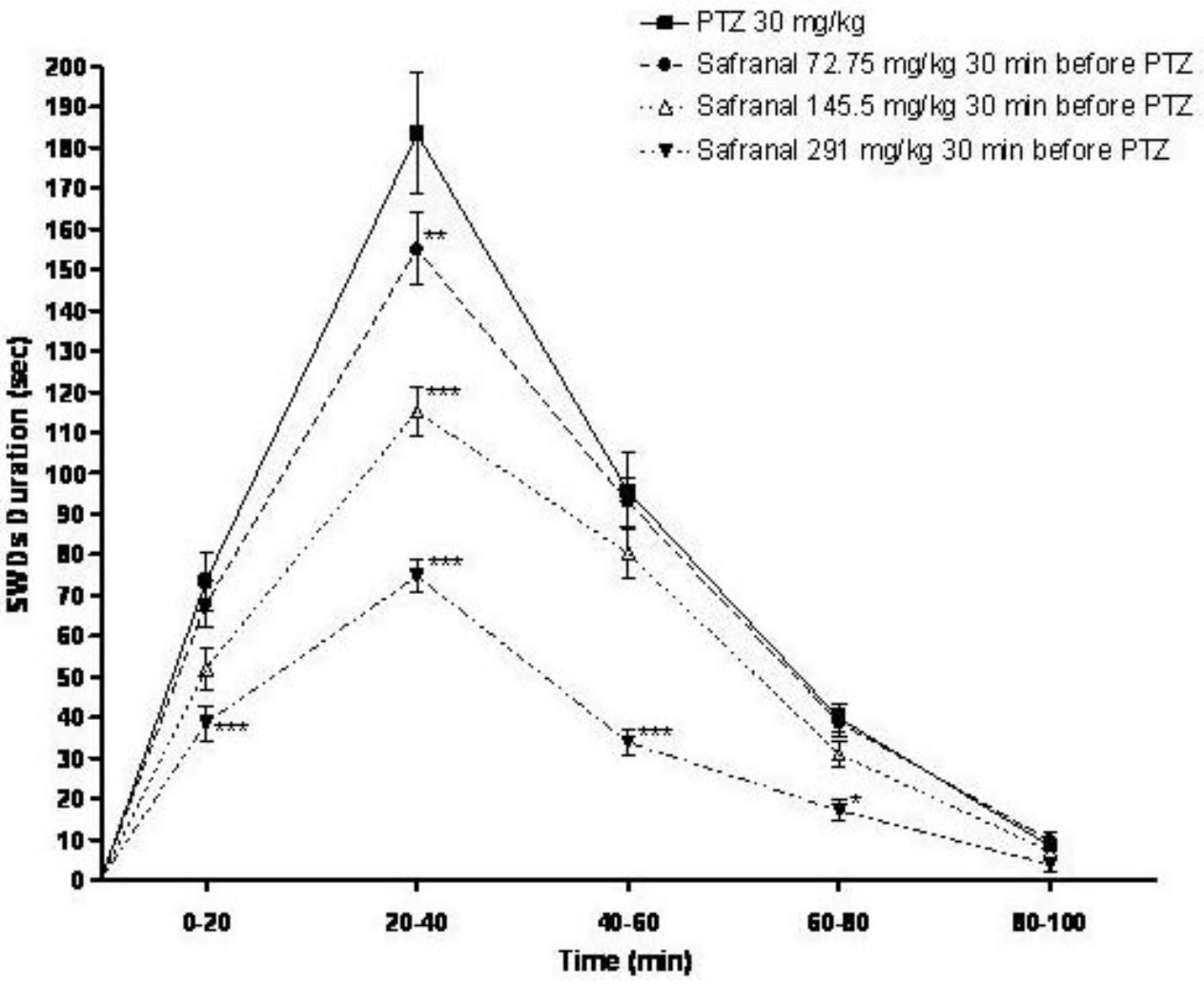


Figure 3 - D

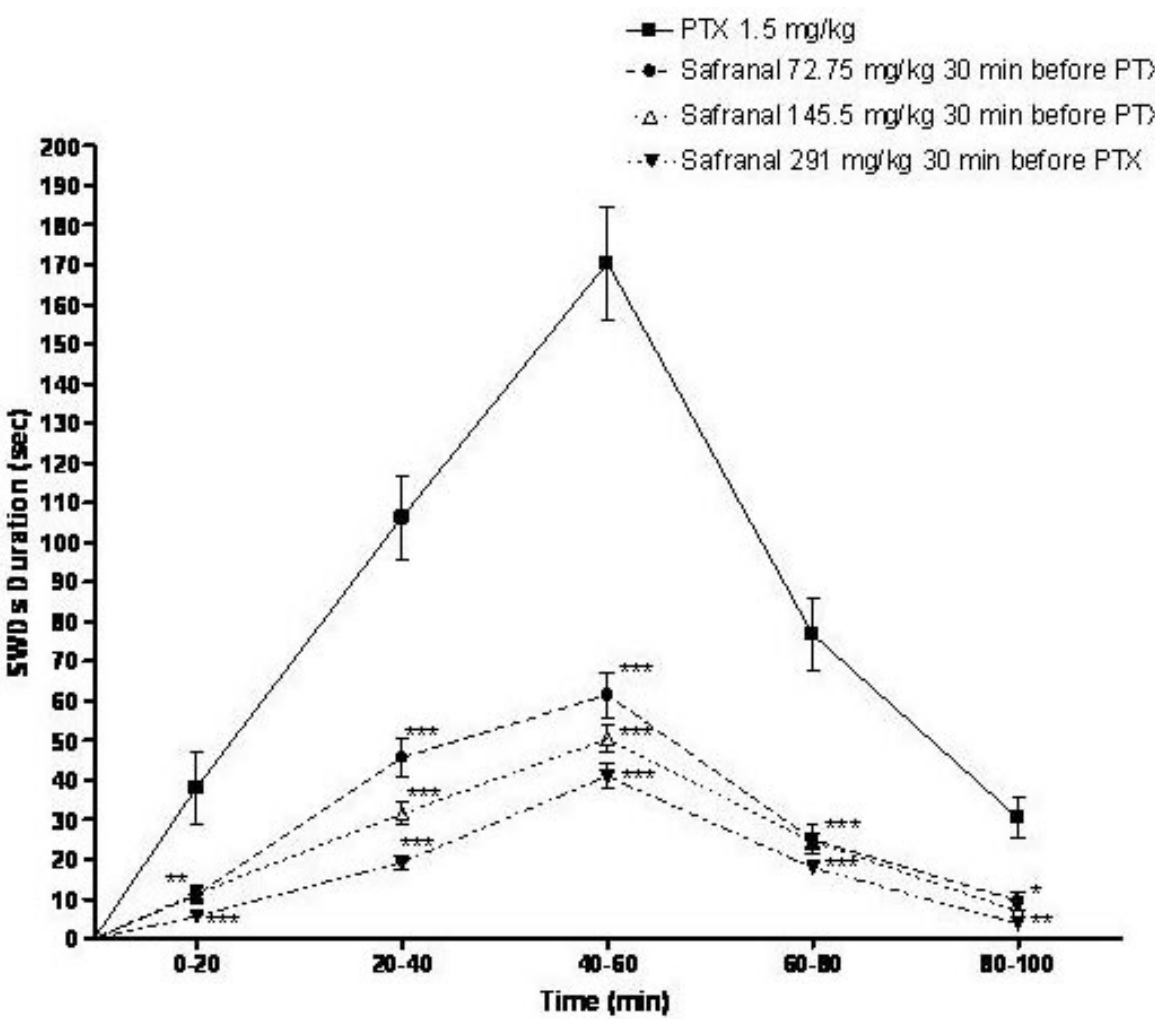

Figure 3 - E

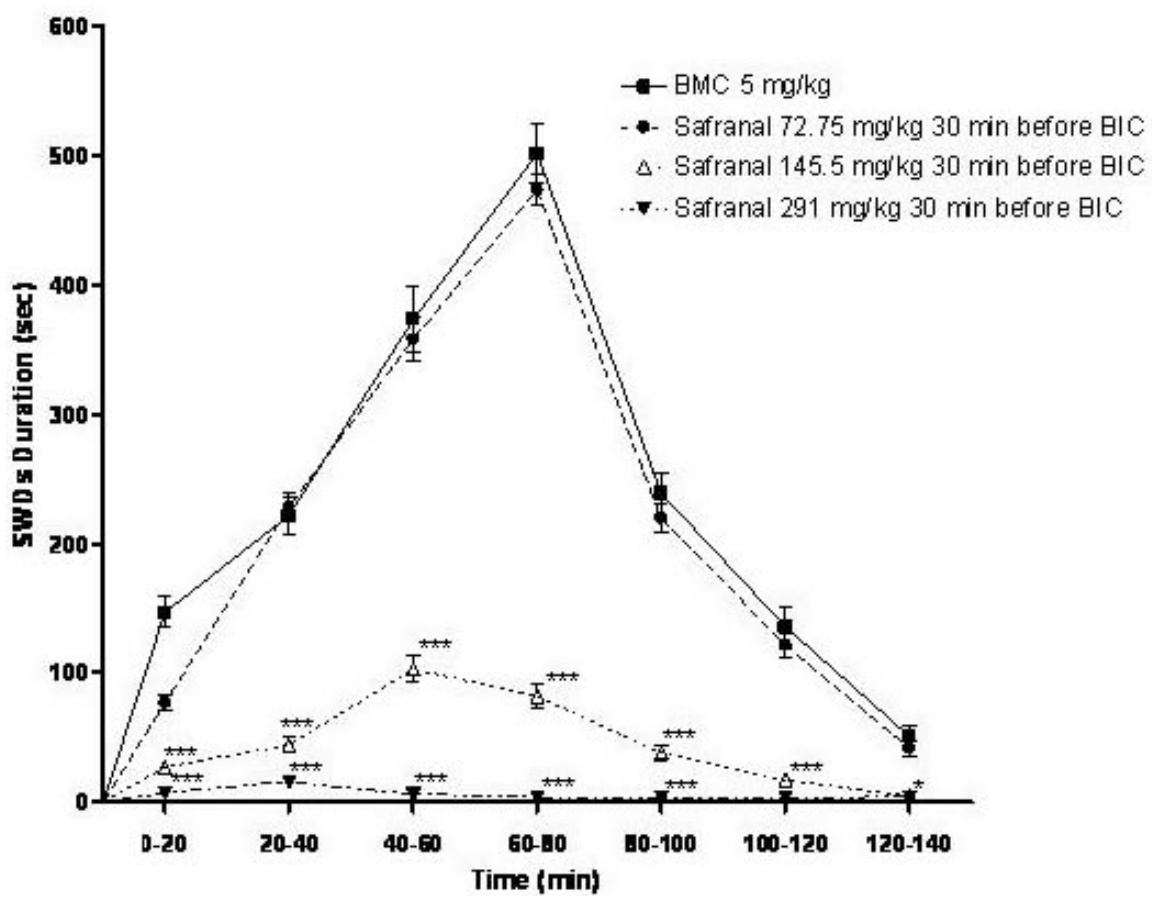

Fig. 3. Effect of safranal on duration of SWD induced by GBL (100 mg/kg), BAC (20 mg/kg), PTZ (30 mg/kg), PTX (1.5 $\mathrm{mg} / \mathrm{kg}$ ) and BMC $(5 \mathrm{mg} / \mathrm{kg})$. All drugs were given intraperitoneally. (A) Effect of safranal on duration of SWD induced by GBL $(100 \mathrm{mg} / \mathrm{kg})$. (B) Effect of safranal on duration of SWD induced by BAC (20 mg/kg). (C) Effect of safranal on duration of SWD induced by PTZ (30 mg/kg). (D) Effect of safranal on duration of SWD induced by PTX (1.5 mg/kg). (E) Effect of safranal on duration of SWD induced by BMC $(5 \mathrm{mg} / \mathrm{kg})$. Values are mean \pm SEM $(\mathrm{n}=6-8) .{ }^{*} \mathrm{p}<0.05,{ }^{*} \mathrm{p}<0.01$, $* * * \mathrm{p}<0.001$ as compared to control group (Two-way ANOVA followed by Bonferroni's test). 


\section{Effect of safranal on regional binding of $\left[^{3} \mathrm{H}\right]$ flunitrazepam and $\left[{ }^{3} \mathrm{H}\right] \mathrm{CGP} 54626 \mathrm{~A}$ binding}

In all autoradiographic experiments, non-specific binding was less than $10 \%$ of the total binding. The data were expressed as percentage of ligands specific binding in control animals. Safranal-treated animals, showed reduced $\left[{ }^{3} \mathrm{H}\right]$ flunitrazepam binding in cortex (33.16\%), hippocampus $(27.36 \%)$ and thalamus $(29.91 \%)$, compared with the saline group.

No significant modification on $\left[{ }^{3} \mathrm{H}\right]$ CGP 54626A regional binding was seen after single administration of safranal (Fig. 4A-F).

Figure 4 - A-D

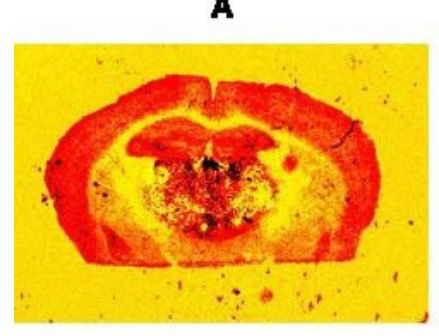

C

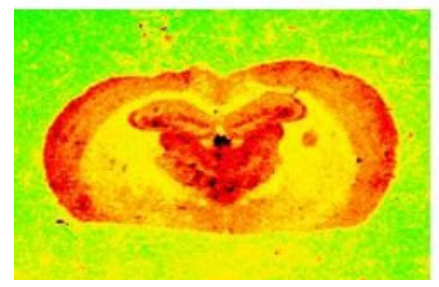

$\mathbf{B}$

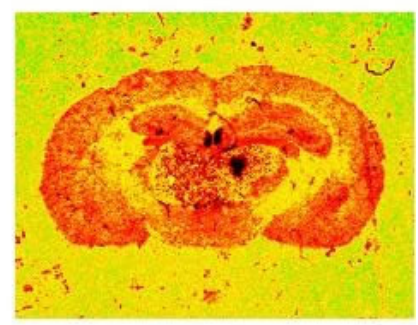

D

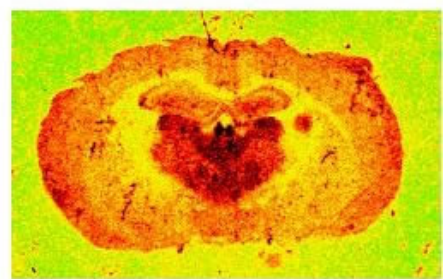

Figure 4-E

Control

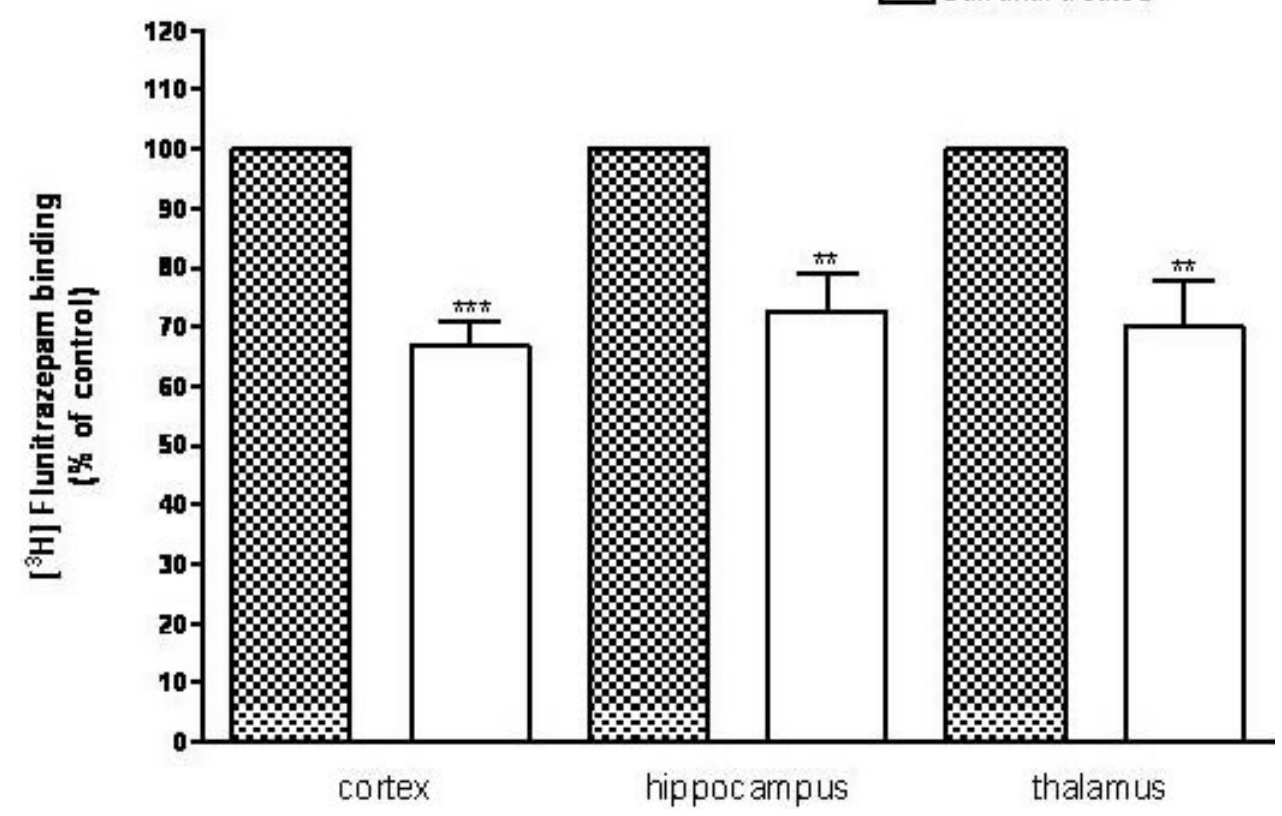




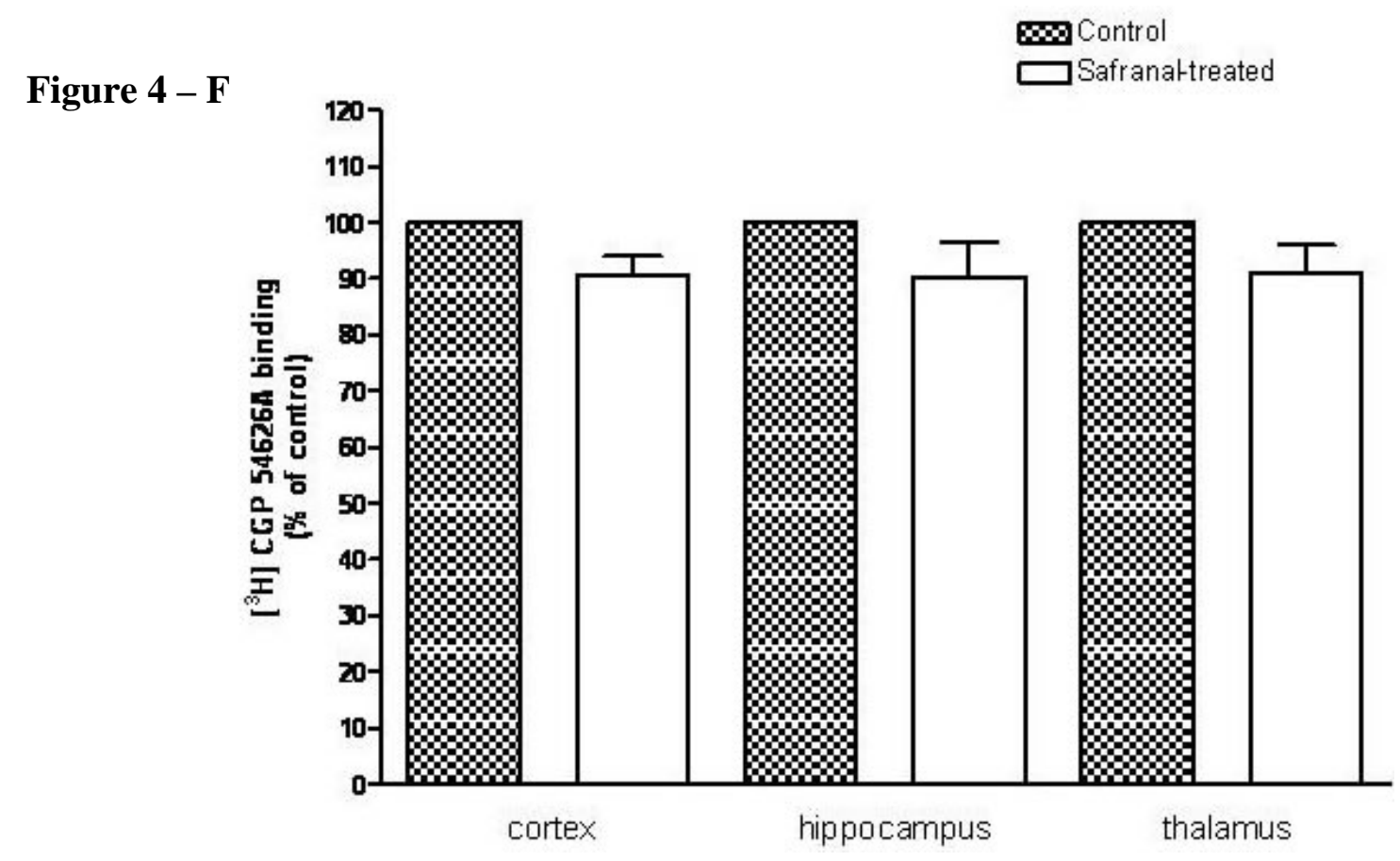

Fig. 4. Effect of a single systemic administration of safranal on regional binding of $\left[{ }^{3} \mathrm{H}\right]$ flunitrazepam and $\left[{ }^{3} \mathrm{H}\right]$ CGP54626A, in mouse brain sections. Mice were treated with either saline (10 ml $/ \mathrm{kg}$, i.p.; control) or safranal (291 mg/kg, i.p.) and after $30 \mathrm{~min}$ the brain was removed and subjected to autoradiography for either $\left[{ }^{3} \mathrm{H}\right]$ flunitrazepam or $\left[{ }^{3} \mathrm{H}\right]$ CGP54626A. (A: control, B: safranal-treated) Representative autoradiograph of $\left[{ }^{3} \mathrm{H}\right]$ flunitrazepam in mouse brain sections. (C: control, D: safranal-treated) Representative autoradiograph of $\left[{ }^{3} \mathrm{H}\right]$ CGP54626A in mouse brain sections. (E) Modification of $\left[{ }^{3} \mathrm{H}\right]$ flunitrazepam-specific binding in various mouse brain regions by safranal. Values are percentages of $\left[{ }^{3} \mathrm{H}\right]$ flunitrazepam-specific binding in control mice (mean $\pm \mathrm{SEM}, \mathrm{n}=4$ ). ${ }^{* *} \mathrm{p}<0.01,{ }^{* * *} \mathrm{p}<0.001$ as compared to control group (two-tailed unpaired t test). (F) Modification of $\left[{ }^{3} \mathrm{H}\right]$ CGP 54626A-specific binding in various mouse brain regions by safranal. Values are percentages of $\left[{ }^{3} \mathrm{H}\right]$ CGP 54626A-specific binding in control mice (mean $\pm \mathrm{SEM}, \mathrm{n}=4$ ). No significant modification was seen. Cx: Cortex, Hip: Hippocampus, Th: Thalamus.

\section{DISCUSSION}

There are three major findings in our study. First, safranal attenuated acute experimental absence seizures elicited by GBL, baclofen and low dose of $\mathrm{GABA}_{\mathrm{A}}$ receptor antagonists (BMC, PTX and PTZ) in mice. Second, while safranal dose-dependently decreased the SWD duration following GBL, baclofen, BMC and PTZ induced absence seizures, no dose-dependent effect on reduction of SWD duration following PTX administration was seen. Third, following a single administration of safranal, $\left[{ }^{3} \mathrm{H}\right]$ flunitrazepam binding significantly reduced in the cortex, hippocampus and thalamus of mouse brain. In contrast, $\left[{ }^{3} \mathrm{H}\right]$ CGP $54626 \mathrm{~A}$ binding did not show any modifications.
GABAergic mechanisms have long been hypothesized to be involved in the pathogenesis of generalized absence seizures (2). While low doses of $\mathrm{GABA}_{\mathrm{A}}$ antagonists induce absence seizures in experimental animals (probably through a decrease in recurrent inhibition in thalamic reticular nucleus, TRN) and both $\mathrm{GABA}_{\mathrm{A}}$ and $\mathrm{GABA}_{\mathrm{B}}$ agonists exacerbate experimental absence seizure activity, only $\mathrm{GABA}_{\mathrm{B}}$ antagonists attenuate or block absence seizures $(2,24)$. The exception is benzodiazepines (BDZ) which are known to augment GABAergic function in the brain but still have therapeutic efficacy in generalized absence seizures. It has been suggested that $\mathrm{BDZ}$ enhance $\mathrm{GABA}_{\mathrm{A}}$-mediated inhibition within the reticular neurons of thalamus and thereby suppress $\mathrm{GABA}_{\mathrm{B}}$-mediated inhibition in relay neurons $(2,25)$. $\gamma$-Hydroxybutyric acid 
(GHB) is a naturally occurring GABA metabolite that has been proposed as a neurotransmitter/neuromodulator that acts via its own receptor. The role of GHB on absence seizures has also been well documented $(18,26,27)$.

GBL, baclofen and low dose of $\mathrm{GABA}_{\mathrm{A}}$ receptor antagonists-induced absence seizures are useful models for the study of generalized absence epilepsy (28). These models have also shown a high predictive value in assessment of clinical efficacy of several anti-absence drugs $(2,3,29,30)$. Therefore, the present data of a dose-dependent attenuation of absence epilepsy following i.p. administration of safranal may have some implications for human therapy.

In these experiments, a significant and dose-dependent decrease in SWD duration of either GBL, or BAC, or BMC or PTZ-induced absence seizures was seen after the systemic administration of safranal, while all doses of safranal decreased SWD duration following PTX administration. Except for PTZ, safranal also increased the latencies to seizure onset induced by GBL, BAC, PTX and BMC, in a dose-dependent manner. Moreover, following single administration of safranal $(291 \mathrm{mg} / \mathrm{kg})$, a significant decrease in $\left[{ }^{3} \mathrm{H}\right]$ flunitrazepam binding was seen in the cortex, hippocampus and thalamus, without any modification in regional binding of CGP 54626A, a $\mathrm{GABA}_{\mathrm{B}}$ receptor antagonist. These findings are consistent with a previous study that showed a protective effect of safranal against both clonic and tonic phases of PTZ-induced seizures and this protection was abolished by flumazenil, a BDZ binding site antagonist (31).

Several hypotheses may explain the attenuation of absence seizures by safranal. Safranal may interact with $\mathrm{BDZ}$ binding site of $\mathrm{GABA}_{\mathrm{A}}$ receptor complex and therefore like other $\mathrm{BDZ}$, acts to facilitate $\mathrm{GABA}_{\mathrm{A}}$ mediated recurrent inhibition within TRN and decrease its $\mathrm{GABA}_{\mathrm{B}}$-mediated inhibitory output onto the ventrobasal nuclei of the thalamus. Safranal could be also acting by enhancing GABAergic inhibition in the cortex and/or hippocampus. This assumption was supported by the finding that $\left[{ }^{3} \mathrm{H}\right]$ flunitrazepam binding was modified by a single systemic administration of safranal in three brain regions were examined.

A large body of evidence indicates that $\mathrm{GABA}_{\mathrm{A}}$ receptors are the targets of a variety of pharmacologically and clinically important drugs. In most cases, these compounds do not interact directly with the GABA binding site but exert their action by binding to additional allosteric sites at $\mathrm{GABA}_{\mathrm{A}}$ receptors. This binding induces a conformational change in the $\mathrm{GABA}_{\mathrm{A}}$ receptors that in turn influences the binding properties of other binding sites present on these receptors and modulates GABA-induced chloride ion flux (32, 33).

It has been suggested that a single $\mathrm{GABA}_{\mathrm{A}}$ receptor complex has several BDZ binding sites and each of these binding sites probably have at least two different conformations: one exhibiting a high and one a low affinity for BDZ agonists. In the undisturbed receptors, these conformations presumably are freely interconvertible $(33,34-36)$. $\left[{ }^{3} \mathrm{H}\right]$ flunitrazepam reversibly binds to the high affinity conformation $(33,35)$ and it is possible that binding of a BDZ ligand to one of the several benzodiazepine binding sites on $\mathrm{GABA}_{\mathrm{A}}$ receptors could allosterically change the conformation and thus the affinity of the other sites for flunitrazepam. This assumption is supported by experiments suggesting cooperative interactions between BDZ binding sites of $\mathrm{GABA}_{\mathrm{A}}$ receptors. It was demonstrated that the rate of dissociation of $\left[{ }^{3} \mathrm{H}\right]$ flunitrazepam from its binding sites in brain membranes is accelerated by the occupation of unlabeled binding sites by diazepam, flunitrazepam, or other BDZ binding site ligands $(37,38)$. A cooperative interaction between several BDZ binding sites present in a single $\mathrm{GABA}_{\mathrm{A}}$ receptor might be one explanation for the observation that a single systemic administration of safranal seems to decrease $\left[{ }^{3} \mathrm{H}\right]$ flunitrazepam binding. However, it is also possible that decrease in $\left[{ }^{3} \mathrm{H}\right]$ flunitrazepam binding by safranal is not necessarily due to an allosteric interaction of binding sites, but could also be due to a competition for individual attachment points on the same binding site $(33,35)$. But depending on the conditions used, discrepancies between the in vivo action of compounds and their apparent in vitro activities (agonist, antagonist or partial agonist) do occur $(33,35)$. The techniques used to determine receptor-binding and brain areas studied, may also affect the results. For example, using brain homogenates, it was recorded that 30 min after systemic acute PTZ injection, as well as chronic administration, the $\left[{ }^{3} \mathrm{H}\right]$ diazepam binding was enhanced $(39,40)$ but other authors failed to 
show significant changes of BDZ-binding $30 \mathrm{~min}$ after administration of convulsive doses of PTZ (41). While other authors, using brain slice, showed that $\left[{ }^{3} \mathrm{H}\right]$ flunitrazepam binding was decreased after single or chronic systemic administration of PTZ in different brain regions (42).

It might be also assumed that safranal interacts with $\mathrm{GABA}_{\mathrm{A}}$ receptor-chloride inophor complex on a specific binding site. Therefore, it is necessary to investigate the kinetics of safranal binding using brain membrane preparations and different probes.

In conclusion, the current experiments showed that safranal attenuated the acute experimental absence seizures and this effect may be due to some modifications on benzodiazepine binding sites of $\mathrm{GABA}_{\mathrm{A}}$ receptor complex.

\section{REFERENCES}

[1]. Berkovic, S.F., Andermann, F., Andermann, E., Gloor, P., Concepts of absence epilepsies: Discrete syndromes or biologic continuum? Neurology, 37: 993-1000, 1987.

[2]. Snead, O.C. $3^{\text {rd }}$. , Basic mechanisms of generalized absence seizures. Ann Neurol, 37:146- 157, 1995.

[3]. Manning, J.P., Richards, D.A., Bowery, N.G., Pharmacology of absence epilepsy. Trends Pharmacol Sci, 24:542-549, 2003.

[4]. Futatsugi, Y., Riviello J.J. Jr., Mechanisms of generalized absence epilepsy. Brain Dev, 20: 7579, 1998.

[5]. Kostopoulos, G.K., Involvement of the thalamocortical system in epileptic loss of consciousness. Epilepsia, 42:13-19, 2001.

[6]. Banerjee, P.K., Snead, O.C. $3^{\text {rd }}$, Presynaptic gamma-hydroxybutyric acid (GHB) and gammaaminobutyric acidB (GABAB) receptor-mediated release of GABA and glutamate (GLU) in rat thalamic ventrobasal nucleus (VB): a possible mechanism for the generation of absence-like seizures induced by GHB. J Pharmacol Exp Ther, 273:1534-1543, 1995.

[7]. Lin, F-H., Wang, Y., Lin, S., Cao, Z., Hosford, D.A., GABAB receptor-mediated effects in synaptosomes of lethargic $(l h / l h)$ mice. J Neurochem, 65:2087-2095, 1995.

[8]. Richards, D.A., Lemos, T., Whitton, P.S., Bowery, N.G., Extracellular GABA in the ventrolateral thalamus of rats exhibiting spontaneous absence epilepsy: a microdialysis study. J Neurochem, 65:1674-1680, 1995.
[9]. Tarantilis, P.A., Tsoupras, G., Polissiou, M., Determination of saffron (Crocus sativus L.) components in crude plant extract using high performance liquid chromatography-UV-visible photodiode-array detection-mass spectrometry. J Chromatogr A, 699:107-118, 1995.

[10]. Hosseinzadeh H., Khosravan V., Anticonvulsant effects of aqueous and ethanolic extracts of Crocus sativus L. stigmas in mice. Arch Irn Med, 5: 44-47, 2002.

[11]. Hosseinzadeh, H., Talebzadeh, F., Anticonvulsant evaluation of safranal and crocin from Crocus sativus in mice. Fitoterapia, 76: 722-724, 2005.

[12]. Hosseinzadeh, H., Sadeghnia, H.R., Safranal, a constituent of Crocus sativus (saffron), attenuated cerebral ischemia induced oxidative damage in rat hippocampus. J Pharm Pharm Sci, 8:394-399, 2005.

[13]. Loscher, W., Honack, D., Fassbender, C.P., Nolting, B., The role of technical, biological and pharmacological factors in the laboratory evaluation of anticonvulsant drugs. III. Pentylenetetrazole seizure models. Epilepsy Res, 8:171-189, 1991.

[14]. Loscher, W., New visions in the pharmacology of anticonvulsion. Eur J Pharmacol, 342:1-13, 1998.

[15]. van Luijtelaar, E.L.J.M., Coenen, A.M.L., Circadian rhythmicity in absence epilepsy in rats. Epilepsy Res, 2:331-336, 1988.

[16]. Coenen, A.M.L., Blezer, E.H.M., van Luijtelaar, E.L.J.M., Effects of the GABA-uptake inhibitor tiagabine on electroencephalogram, spike-wave discharges and behaviour of rats. Epilepsy Res, 21: 89-94, 1995.

[17]. Snead, O.C. 3rd, Banerjee, P. K., Burnham, M., Hampson D., Modulation of absence seizures by the GABA(A) receptor: a critical role for metabotropic glutamate receptor 4 (mGluR4). J Neurosci, 20:6218-6224, 2000.

[18]. Snead, O.C. 3rd, Hechler, V., Vergnes, M., Marescaux C., Maitre, M. Increased gammahydroxybutyric acid receptors in thalamus of a genetic animal model of petit mal epilepsy. Epilepsy Res, 7:121-128, 1990.

[19]. Bischoff, S., Leonhard, S., Reymann, N., Schuler, V., Shigemoto, R., Kaupmann, K., Bettler, B., Spatial distribution of GABA(B)R1 receptor mRNA and binding sites in the rat brain. J Comp Neurol, 412:1-16, 1999.

[20]. Wu, Y., Ali, S., Ahmadian G., Liu C.C., Wang, Y.T., Gibson, K.M., Calver, A.R., Francis, J., Pangalos, M.N., Snead O.C. $3^{\text {rd }}$., Gammahydroxybutyric acid (GHB) and gammaaminobutyric acidB receptor (GABABR) binding sites are distinctive from one another: molecular 
evidence. Neuropharmacology, 47:1146-1156, 2004.

[21]. Carlson, B.X., Mans, A.M., Hawkins, R.A., Baghdoyan, H.A., Pentobarbital-enhanced [3H] flunitrazepam binding throughout the rat brain: An autoradiographic study. J Pharmacol Exp Ther, 263:1401-1414, 1992.

[22]. Wu, Y., Buzzi, A., Frantseva, M., Velazquez, J.P.L., Cortez, M., Liu, C., Shen, L., Gibson, K.M., Snead O.C., Status epilepticus in mice deficient for succinate semialdehyde dehydrogenase: GABAA receptor-mediated mechanisms. Ann Neurol, 59:42-52, 2006.

[23]. Snead, O.C. 3rd, Evidence for a G proteincoupled gamma-hydroxybutyric acid receptor. J Neurochem, 75:1986-1996, 2000.

[24]. Snead, O.C. 3rd, Evidence for GABAB-mediated mechanisms in experimental absence seizures. Eur J Pharmacol, 213:343-349, 1992.

[25]. Wong, C.G., Snead, O.C. 3rd, The GABA(A) receptor: Subunit-dependent functions and absence seizures. Epilepsy Curr, 1:1-5, 2001.

[26]. Snead, O.C. 3rd, The gamma-hydroxybutyrate model of absence seizures: Correlation of regional brain levels of gamma-hydroxybutyric acid and gamma-butyrolactone with spike wave discharges. Neuropharmacology, 30:161-167, 1991.

[27]. Crunelli, V., Emri, Z., Leresche, N., Unraveling the brain targets of gamma-hydroxybutyric acid. Curr Opin Pharmacol, 6: 44-52, 2006.

[28]. Snead, O.C. 3rd, Depaulis, A., Vergnes, M., Marescaux, C., Absence epilepsy: advances in experimental animal models. Adv Neurol, 79:253-278, 1999.

[29]. Holmes, G.L., Models for generalized seizures. Suppl Clin Neurophysiol, 57:415-424, 2004.

[30]. Posner, E., Pharmacological treatment of childhood absence epilepsy. Expert Rev Neurother, 6:855-862, 2006.

[31]. Hosseinzadeh, H., Sadeghnia, H.R., Protective effect of safranal on pentylenetetrazol-induced seizures in the rat: Involvement of GABAergic and opioids systems. Phytomedicine, 14:256-262, 2007.

[32]. Sieghart, W., GABAA receptors: ligand-gated Clion channels modulated by multiple drug-binding sites. Trends Pharmacol Sci, 13:446-450, 1992.

[33]. Sieghart, W., Structure, pharmacology, and function of GABAA receptor subtypes. Adv Pharmacol, 54:231-263, 2006.

[34]. Monod, J., Wyman, J., Changeux, J.P., On the nature of allosteric transitions: a plausible model. J Mol Biol,12:8-118, 1965.

[35]. Sieghart, W., Structure and pharmacology of gamma-aminobutyric AcidA receptor subtypes. Pharmacol Rev, 47:181-234, 1995.

[36]. Walters, R.J., Hadley, S.H., Morris, K.D., Amin, J., Benzodiazepines act on GABAA receptors via two distinct and separable mechanisms. Nat Neurosci, 3:1274-1281, 2000.

[37]. Doble, A., GABA abolishes cooperativity between benzodiazepine receptors. Eur J Pharmacol, 83:313-316, 1982.

[38]. Chiu, T.H., Rosenberg, H.C., Allosteric modulation of flunitrazepam binding to rat brain benzodiazepine receptors by methyl betacarboline-3-carboxylate. J Neurochem, 44:306309, 1985.

[39]. Paul, S.M., Skolnick, P., Rapid changes in brain benzodiazepine receptors after experimental seizures. Science, 202:892-893, 1978.

[40]. Syapin, P.J., Rickman, D.W., Benzodiazepine receptor increase following repeated pentylenetetrazole injections. Eur J Pharmacol, 72:117-120, 1981.

[41]. Ito, M., Chiu, T.H., Rosenberg, H.C., Effects of pentylenetetrazol on GABAA/benzodiazepine/picrotoxinin receptor complexes in rat brain regions. Neurochem Res, 11:637-646, 1986.

[42]. Rocha, L., Ackermann, R.F., Engel J. Jr., Chronic and single administration of pentylenetetrazol modifies benzodiazepine receptor-binding: an autoradiographic study. Epilepsy Res, 24:65-72, 1996. 